Recorregut de recerca de geològica i mineralògica per la comarca de I'Alta Ribagorça: des de les Mines de Malpàs a Adons i a Corroncui

Josep Maria Mata-Perelló

Joaquim Sanz Balagué

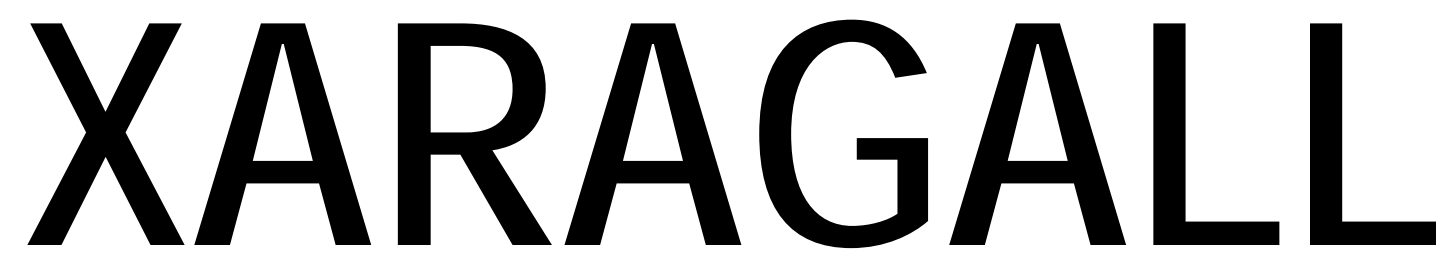

REVISTA DE CIÈNCIES DE LA CATALUNYA CENTRAL

ก. 9

SETEMBRE 2014

Com citar l'article: Mata-Perelló, JM.; Sanz Balaguer, J. Recorregut de recerca de geològica i mineralògica per la comarca de l'Alta Ribagorça: des de les Mines de Malpàs a Adons i a Corroncui. A: XARAGALL. Revista de Ciències de la Catalunya Central. 2014. (n.9). ISSN 2013-4479 DL: B.214832009. DOI 


\section{RECORREGUT DE RECERCA DE GEOLÒGICA I MINERALÒGICA PER LA COMARCA DE L'ALTA RIBAGORÇA: DES DE LES MINES DE MALPÀS A ADONS I A CORRONCUI}

\section{Josep Maria Mata-Perelló}

Museu de geologia Valentí Masachs, Escola Politècnica Superior d'Enginyeria de Manresa (EPSEM), Universitat Politècnica de Catalunya · BarcelonaTech (UPC), 08272 Manresa, Spain

\section{Joaquim Sanz Balagué}

Departament d'Enginyeria Minera i Recursos Naturals (EMRN), Escola Politècnica Superior d'Enginyeria de Manresa (EPSEM), Universitat Politècnica de Catalunya · BarcelonaTech (UPC), 08272 Manresa, Spain

Paraules clau: Sistema Pirinenc, Unitat de les Nogueres, Mantell dels Bòixols, Patrimoni miner

\section{Resum}

Itinerari realitzat el 22 de setembre de 2013. En aquesta ocasió, la totalitat del present recorregut de l'itinerari discorrerà pel Sistema Pirinenc (i més concretament per la denominada Unitat de les Nogueres així com pel Mantell de Bóixols, en els darrers trams del recorregut de I'itinerari.

Així, el recorregut s'iniciarà a les conegudes Mines de Malpàs, situades dintre de la Unitat de les Nogueres. Després, el recorregut es dirigirà cap el Sud, fins trobar la carretera N - 260, per la qual s'anirà cap al Viu de Llevata. Aquest tram ja s'efectuarà dintre del Mantell de Bóixols, el qual ja no s'abandonarà fins a la fi del recorregut de l'itinerari.

Per d'altra banda, el recorregut s'efectuarà exclusivament dintre de la comarca de l'Alta Ribagorça, per on s'iniciarà a les esmentades Mines de Malpàs: finalitzant prop de Perbes i de la comarca del Pallars Jussà, a la qual no s'arribarà en tot aquest tram final del recorregut. 


\section{Objectius fonamentals}

Els objectius fonamentals que es pretenen aconseguir en aquest itinerari, es poden concretar en els següents aspectes generals:

1. Observació dels materials paleozoics (del Devonià, Carbonífer i Permià) i dels mesozoics (del Triàsic) que formen part de la Unitat del Mantell de les Nogueres. Hi transitarem per ells entre les Mines de Malpàs i la cruïlla amb la carretera N - 260.

2. Observació i descripció dels materials secundaris (del Cretàcic), que formen part del Mantell de Bóixols (concretament de la Serra de Sant Gervasi), per on transitarem entre el pont del riu Paranera de la carretera N - 260 i la la fi del recorregut, prop de Perbes.

3. Observació del contacte entre les unitats geològiques acabades d'esmentar, i de les relacions entre elles.

4. Reconeixement de diverses mineralitzacions, que anirem trobant al llarg del recorregut. Aquestes, d'acord amb el sentit de la marxa, seran les següents:

4A) les mineralitzacions ferruginoses associades a alteracions de pirites, les veurem a Malpàs. Es troben associades a nivells carbonosos del Carbonífer del Mantell de les Nogueres

4B) de les mineralitzacions calcosilicatades associades als afloraments d'ofites, les veurem a Malpàs, dintre del Mantell de les Nogueres, entre els afloraments triàsics del Keuper.

4C) si s'escau, de les mineralitzacions ferruginoses de rebliment de cavitats d'origen kàrstic. En tot cas, les veurem al Viu de Llevata, entre els materials cretàcics del Mantell de Bóixols.

5. Estudi de les explotacions mineres associades amb les mineralitzacions anteriors; i també de les explotacions de roques carbonatades cretàciques, que trobarem prop de Adons, entre els materials del Mantell de Bóixols.

6. Visió de l'impacte produït sobre el Medi Natural, com a conseqüència de les explotacions mineres anteriors. I, tanmateix de la restauració del mateix.

7. Valorització del diferents indrets del Patrimoni Geològic i Miner que anem trobant al llarg del recorregut. 


\section{Antecedents}

Per la nostra banda, no tenim cap antecedent bibliogràfic relatiu a la totalitat del recorregut d'aquest itinerari. Hi ha, però, diversos antecedents parcials, relatius als darrers trams del recorregut. Entre aquests, farem esment dels següents: Mata-Perelló (1995, 1996a, 1996b, 1998, 2000, 2001, 2002 i 2013). També cal fer esment del treball de Mata-Perelló i Mata LLeonart (2000).

Pel que fa a la descripció de les mineralitzacions situades a les comarques per les quals discorre l'itinerari, farem esment d'uns altres treballs nostres; concretament de Mata-Perelló (1990a, 1990b, 1991 i 1992) i de Mata-Perelló i sanz Balagué (1988 i 1993). En aquest sentit, també farem esment de l’important treball de Maestre (1845).

I, finalment, pel que fa a l'estructura geològica de la zona per la qual discorre l'itinerari, farem esment dels treballs generalistes de: Guimerà et altri (1982) i de Riba et altri (1976), tots dos referents al conjunt dels Països Catalans.

Tots aquests treballs i d'altres, figuren esmentats per ordre alfabètic a l'apartat dedicat a la BIBLIOGRAFIA ESMENTADA.

\section{Recorregut de l'itinerari}

Així, el recorregut de l'itinerari, śiniciarà a la Vall de Malpàs, concretament a les Mines de Malpàs. En aquest indret ja s'efectuarà la primera aturada. Després, per la carretera local L 5212, s'anirà cap el pont del riu Paranyera (o Noguera de Paranyera), per la carretera nacional $\mathrm{N}-260$, on hi ha la cruilla de carreteres. Poc abans d'arribar-hi, es farà una nova aturada.

Després, el recorregut continuarà per l'esmentada carretera N-260, ascendint ara el Pas de Llevata. En arribar a dalt, al Viu de Llevata, podrà fer-se una nova aturada, si es dona el cas. Després es continuarà, fins trobar el trencall d'Adons, que ens caldrà agafar, tot fent una nova fillola, amb la finalitat de fer una nova aturada.

Després de retornar a la carretera N-260, ens caldrà seguir-la, pujant ara el Port de Perbes. En arribar a dalt es farà una nova parada, agafant la carretera que condueix cap a Corroncui, per on finalitzarà el recorregut de l'itinerari.

\section{Advertiments previs}

Com en altres recorreguts de RECERCA GEOLÒGICA I MINERALÒGICA ..., si es disposa del temps suficient, poden efectuar-se passant per totes les parades i filloles. En cas contrari, recomanem prescindir de les anomenades PARADES - CONDICIONALS.

També cal fer esment, de que alguns trams del recorregut es faran per camins en mal estat de conservació, per la qual cosa serà millor fer-los a peu. Aquest és el cas del camí d'aproximació cap a les Mines de Malpàs.

En qualsevol cas, i com és natural, cal tenir sempre una cura molt especial de respecte a la natura, al llarg de tot el recorregut de l'itinerari. 


\section{Descripció de l'itinerari}

Com de costum, estructurarem el recorregut de l'itinerari en una sèrie de PARADES, que tot seguit anirem veient. En cadascuna d'aquestes aturades farem un breu comentari (geològic o mineralògic, segons s'escaigui).

Per altra banda, en cada cas indicarem, entre parèntesi, el full topogràfic on es troba l'aturada. Per fer-ho, utilitzarem els fulls editats per I'Instituto Geográfico y Catastral de España, publicats a l'escala de 1:50.000. En aquest cas, els fulls seran els següents: 213 (o del Pont de Suert), 214 (dit de Sort), 251 (o d'Areny) i 252 (també conegut com a full de Tremp)

Així doncs, la relació de les aturades que composen el recorregut d’aquest itinerari, és la següent:

\subsection{Parada 1. MINES DE MALPÀS (Erill-Castell, antic terme de Malpàs, i actual del de Pont de Suert, comarca de l'Alta Ribagorça). (Full 213).}

El recorregut de l'itinerari el farem en aquest emblemàtic indret miner, de la recent història de la mineria i de les industries hidroelèctriques del Pirineu. Aquí hi haurem arribat des del poble de Malpàs, a través de un camí asfaltat (fins a mig recorregut) i després per un camí de terra en no gaires bones condicions. Així, des del poble caldrà fer el recorregut d'uns $3 \mathrm{Km}$ i escaig. Així, haurem arribat a aquest indret situat als peus del vell poble d'Erill-Castell, i enfront del de Paranyera

En aquest indret hi ha unes antigues explotacions carbonoses, a les quals s'aprofitaven uns importants nivells d'hulles incloses entre els materials del Carbonífer Superior i del Pèrmic, que pertanyen a la Formació Malpàs. Aquest indret es troba al bell mig de la Unitat de les Nogueres. Sovint es veuen escombreres de les antigues explotacions. (fotografía 1).

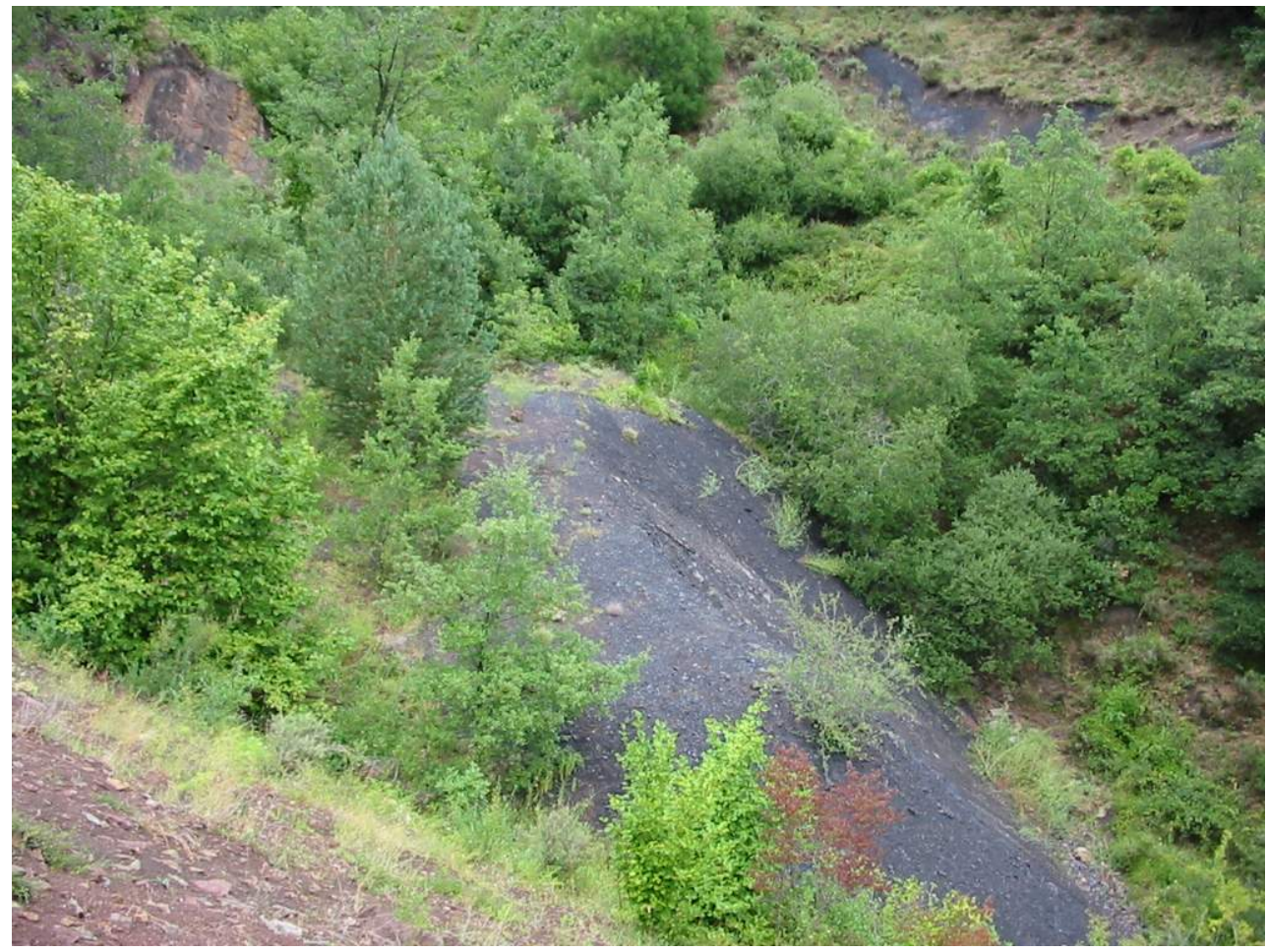

Fotografia 1. Una de les antigues escombreres / Abril 2000 
Entre les hulles es troben diverses mineralitzacions eminentment ferruginoses, amb presència de: MARCASSITA. MELNIKOWITA (indicis), PIRITA (abundant, i sovint ben cristal-litzada), GOETHITA (limonítica), HEMATITES (poc abundant), SIDERITA (indicis), MELANTERITA i SIDEROTÍl. Amb els anteriors, també es troben altres minerals com: SOFRE (indicis), CALCITA, GUIX, CAOLINITA i QUARS, entre altres.

També cal fer esment de l'important patrimoni miner que hi ha en aquest indret: galeries, antigues instal-lacions dels carregadors, pontets dels ferrocarrils miners. Tot i el seu valor, a I'actualitat es troben en un avançat procés de degradació, fent-se força evident que cal una acció decidida per tal de salvaguardar aquest patrimoni. FOTOGRAFIA 2

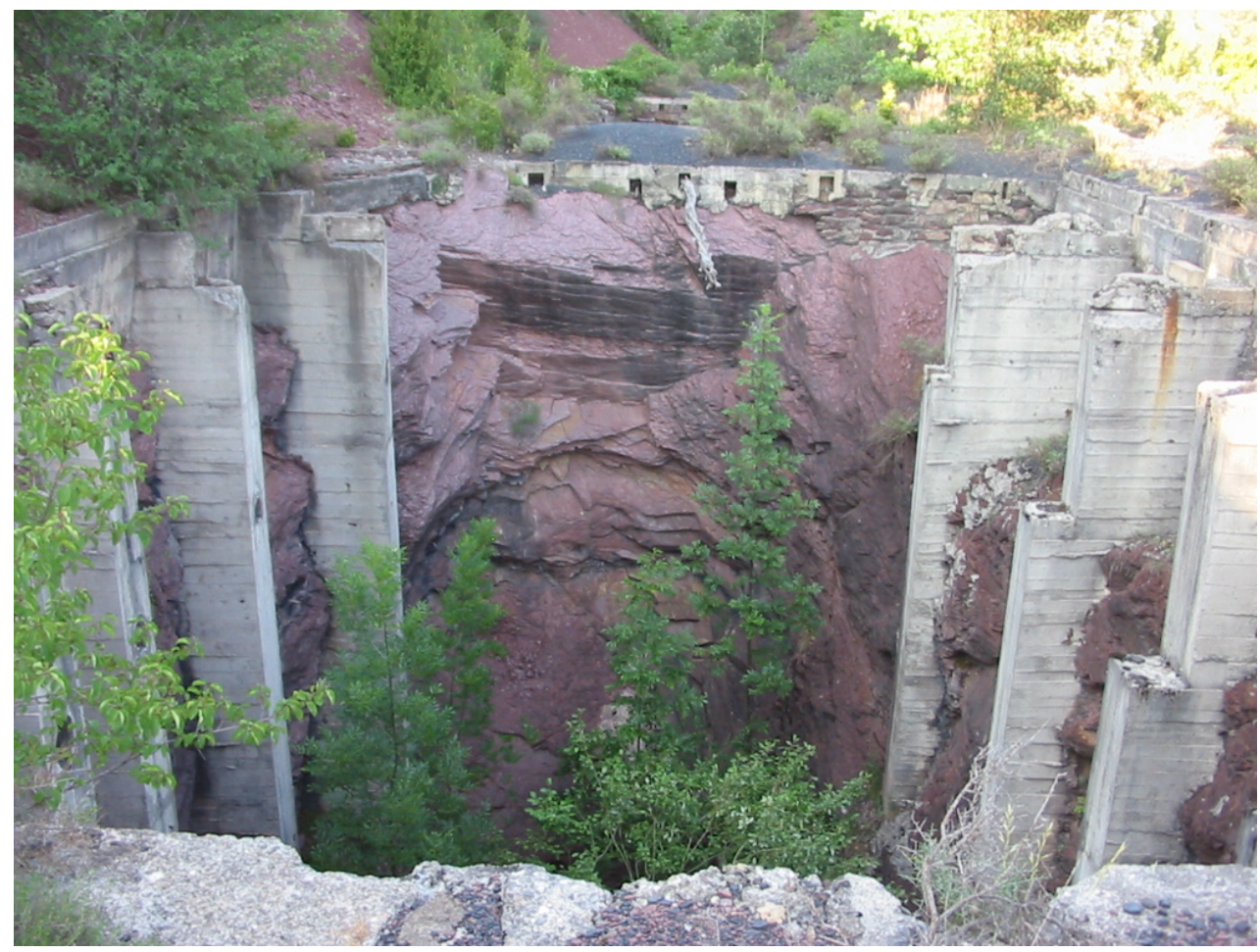

Fotografia 2. Base d’un dels ponts, per on circulava la línia fèrria, que anava de les mines cap a les tremuges. Externes / Abril 2007

Les darreres explotacions, situades en aquest indret, es van tancar a finals dels anys seixanta, just després de la construcció de les grans presses situades al llarg del Noguera Ribagorçana. 


\subsection{Parada 2. INICI DE LA CARRETERA LOCAL A MALPÀS, PONTET SOBRE EL RIU PERANERA, (Malpàs, actualment del terme del Pont de Suert, comarca de l'Alta Ribagorça). (Full 213).}

Després de fer la parada anterior, cal fer un breu recorregut, de poc menys de $3 \mathrm{Km}$, per la carretera que condueix cap a la cruïlla amb la carretera $\mathrm{N}-260$. Així, des de la parada anterior, ens caldrà tornar a Malpàs, i tot seguint la carretera local $L-5212$. Poc abans d'arribar a la cruïlla, farem una nova aturada.

En aquest recorregut, hem anat trobant els materials esmentats a la parada anterior, els quals pertanyen al Carbonífer i al Pèrmic. Més endavant, haurem començat a trobar afloraments dels materials del Triàsic Superior (al Keuper). Així, es fàcil veure trams d'argiles guixoses i afloraments d'ofites.

En aquest indret hi ha un aflorament dels materials del Keuper, amb nivells de guixos $\mathrm{i}$ d'argiles. I també amb la presència d'un important aflorament d'ofites. (fotografia 3).

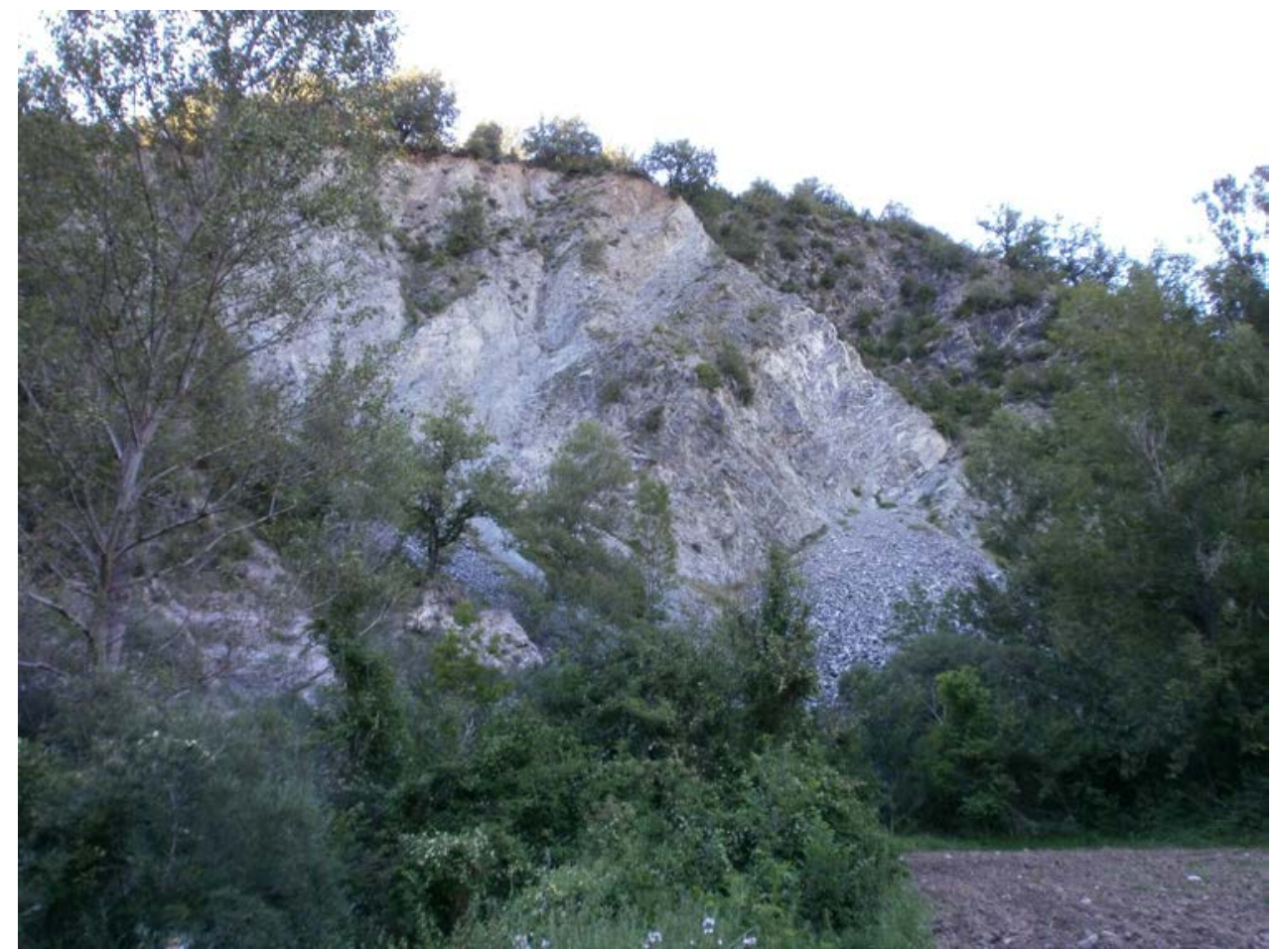

Fotografia 3. Aflorament de les ofites, al costat del riu Paranyera, prop de Malpàs.

Agost del 2013

Precisament, en aquestes darreres es fa palesa l'existència de cristal-litzacions d'EPIDOT (d'aspecte microcristal.lí i d'un intens color verd) i de PREHNITA (d'aspecte globular, i molt ben cristal-litzada). També cal fer esment de la presència de petits cristalls de PIRITA, entre l'epidot.

Per d'altra banda, entre els nivells guixosos i argilosos, es troben petits cristallets de GIOBERTITA (fosca) i de QUARS (rogenc, en forma de Jacints de Compostel.la), juntament amb el GUIX i amb el CAOLÍ. 


\subsection{Parada 3 - CONDICIONAL. PONT DE MALPÀS, CARRETERA N-260, (Malpàs, actualment del terme municipal del Pont de Suert, comarca de I'Alta Ribagorça). (Full 213).}

Des de la parada anterior, sols continuar per la carretera nacional local $L-5212$, tot anant cap el Sud. En arribar a la cruïlla amb la carretera nacional N - 260, es trobarà aquest pont. Aquí, prop d'aquest pont, farem la present aturada, després de recórrer uns 0'250 Km, des de la parada anterior.

En aquest breu recorregut hem anat trobant els materials esmentats a les parades anteriors. Així, haurem anant trobant afloraments dels guixos i argiles triàsiques (del Keuper), els quals formen part de la Unitat dels Mantells de les Nogueres, on encara continuem situats. Tot i així, aquest recorregut s'ha efectuat per molt prop del contacte amb les calcàries cretàciques que formen part del Mantell de Bóixols. Aquestes calcàries es situen a l'altra banda del riu.

\subsection{Parada 4. EL PAS DE LLEVATA, (el Viu de Llevata, actualment pertany al terme del Pont de Suert, comarca de I’Alta Ribagorça). (Fulls 213 i 214).}

Des de la parada anterior, cal seguir ara per la carretera N-260, per la qual caldrà començar a pujar el Port del Pas de Llevata, arribant al poble del Viu de Llevata, on farem la present aturada, després de recórrer uns $7 \mathrm{Km}$ des de la parada anterior.

En aquest recorregut haurem entrat als contraforts septentrionals de la Serra de Sant Gervasi (dintre de la Mantell de Bóixols), trobant-nos freqüents afloraments dels materials mesozoics del Triàsic Superior (del Keuper, ja esmentats abans), així com del Cretàcic (amb nivells carbonatats).

Al Viu de Llevat es fa força palès un tram de calcàries, gairebé verticalitzat, que destaca sobre el paisatge, i on s'ha situat la població, totalment arrecerada font els vents frescs del Nord.

Entre aquests nivells hi ha mineralitzacions ferruginoses de rebliment kàrstic, situades entre les calcàries. Els minerals presents són la GOETHITA (limonítica) i I'HEMATITES; així com la CALCITA (PARADA 4 - BIS).

\subsection{PARADA 5. PEDRERES D’ADONS, (Adons, actualment pertany al terme del Pont de Suert, comarca de l'Alta Ribagorça). (Fulls 251 i 252).}

Després de fer l'aturada anterior, cal baixar cap a la vessant oriental del Pas de Llevata, seguint sempre la carretera nacional $\mathrm{N}-260$, fins a trobar la carretera local que es dirigeix cap al poble d'Adons, la qual ens caldrà agafar per tal de fer una fillola. Poc abans d'arribar-hi, farem una nova aturada, a menys de $4 \mathrm{~km}$ de l'anterior.

En aquest recorregut, hem continuat trobant afloraments de les roques carbonatades cretàciques, les quals formen part de la Serra de Sant Gervasi (integrant del Mantell de Bóixols, on estem situats). Precisament, apareixen a l'indret de l'aturada, han estat explotades aquestes calcàries cretàciques, per tal d'ésser utilitzades com a àrids per a la construcció i per a les obres públiques. 


\subsection{Parada 6. COLL DE PERBES, (Perbes, actualment pertany al terme del Pont de Suert, comarca de I'Alta Ribagorça). (Full 252).}

A continuació de l'aturada anterior, cal retornar cap a la carretera N-260, per tal de continuar cap a ponent, pujant ara cap el de Coll de Perbes. En arribar al punt més alt d'uns 1325 metres, just des d'on eix la carretereta de Corroncui), ens caldrà fer una nova aturada. Així, des de la parada anterior, haurem efectuat un recorregut aproximat d'uns $4 \mathrm{Km}$ i escaig, per tal d’arribar fins aquí.

En aquest trajecte, hem continuat trobant els materials esmentats a la parada anterior, els quals formen part del Mantell de Bóixols, en el qual ens continuem trobant ara, a l'indret de l'aturada.

Des d'aquest lloc es pot gaudir d'un interessant punt d'observació. Així, mirant cap al Nord es poden veure els relleus de la Vall de Manyanet, entre afloraments del Mantell de les Nogueres i afloraments de la Zona Axial Pirinenca. També els de la Vall Fosca, de característiques similars a I'anterior. (fotografia 4).

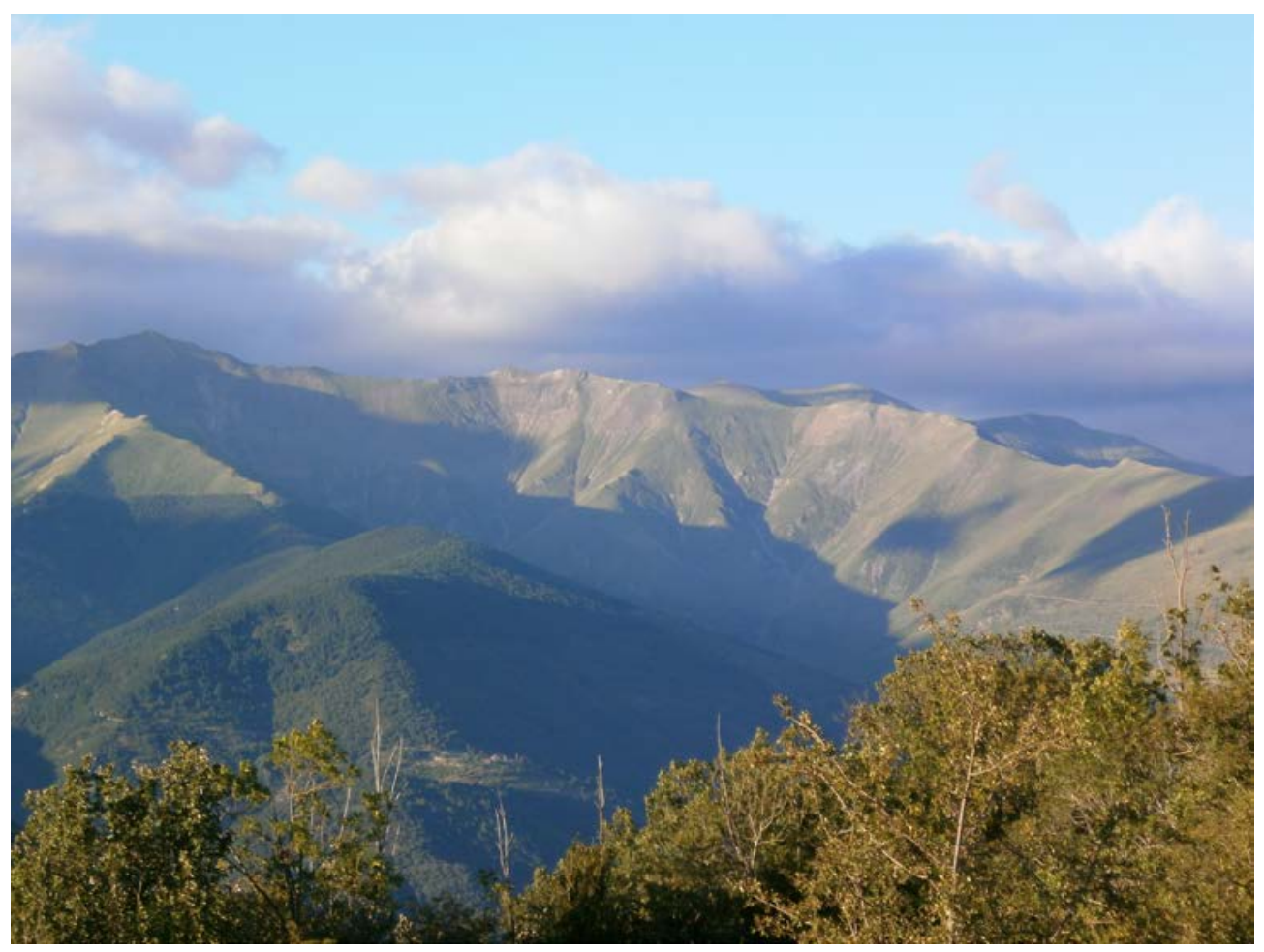

Fotografia 4. Capçalera de la Vall de Manyanet, des del Coll de Perbes.

Agost del 2013

Tanmateix, mirant cap al WSW i cap a ponent, es pot veure l'impressionat anticlinal de la Serra de Sant Gervasi, de naturalesa calcària, entre els materials cretàcics del Mantell de Bóixols. 


\subsection{Parada 7. IMMEDIACIONS DE CORRONCUI, (Corroncui, de I'antic terme del Viu de Llevata, actualment pertany al terme del Pont de Suert, comarca de I’Alta Ribagorça). (Full 252).}

A continuació de l'aturada anterior, cal agafar la carretereta que condueix cap al petit poble de Corroncui, tot sortint de la carretera N - 260 (per la dreta), des del Coll de Perbes. Poc abans d'arribar al poble, a uns $2 \mathrm{Km}$ de la parada anterior, realitzarem una nova aturada, la darrera d'aquest itinerari.

En aquest recorregut, hem anat circulant entre els afloraments dels materials mesozoics del Cretàcic, els quals formen part del Mantell de Bóixols, on estem ara situats, entre aquests afloraments carbonatats.

Des d'aquest indret, mirant cap a ponent, es pot veure la Serra de Sant Gervasi, d'aquest mateix mantell. Així, podem veure l'interessant Anticlinal de Sant Gervasi (o Anticlinal $d^{\prime}$ Adons), situat a ponent d'aquest darrer poble. Així, es poden veure els materials carbonatats del Cretàcic, formant aquest interesant plec. (fotografia 5 )

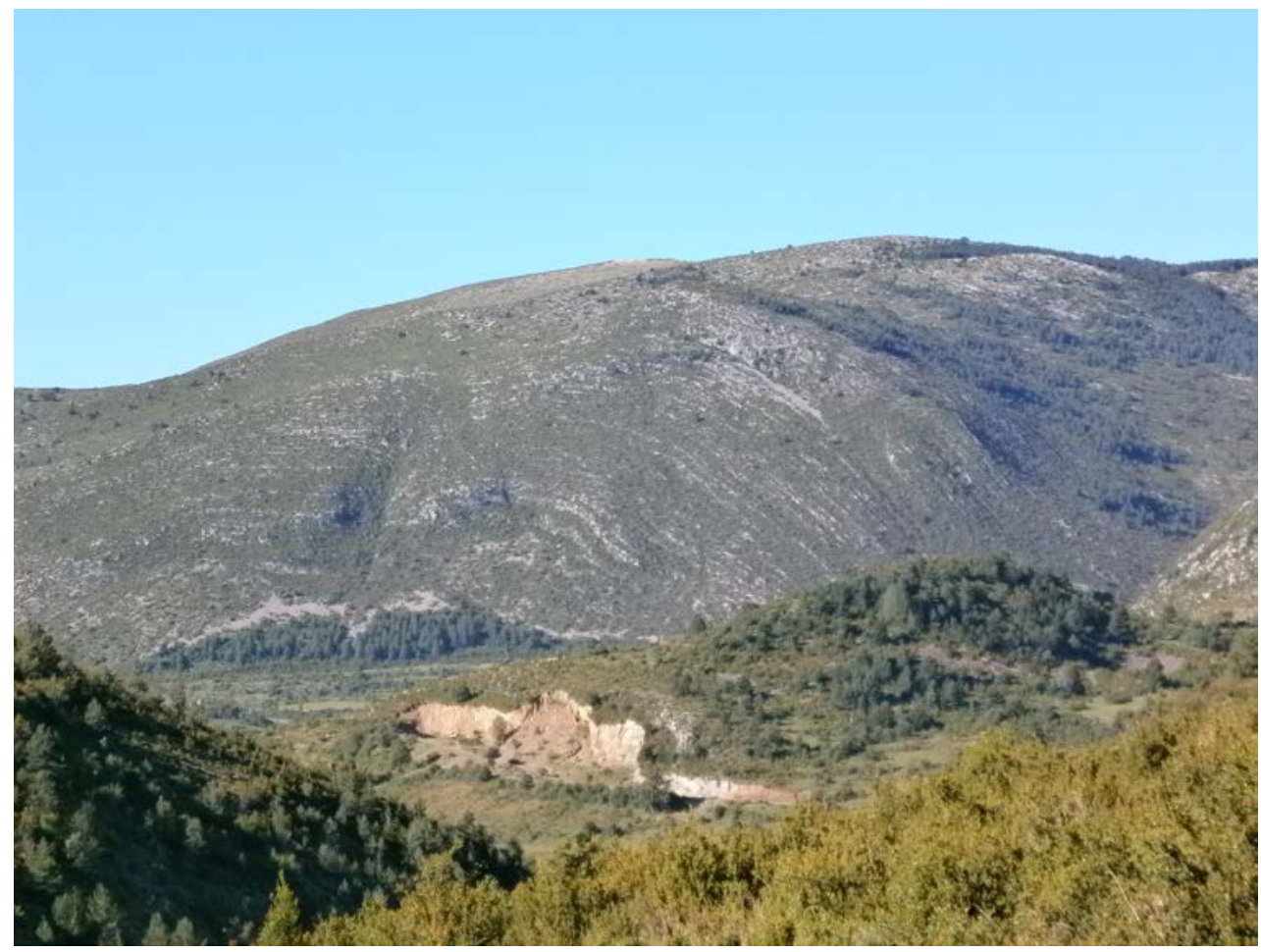

Fotografia 5. Anticlinal de la Serra de Sant Gervasi. En primer terme la graveres de la PARADA 5 / Agost del 2013.

En aquest indret finalitza el recorregut de l'itinerari. 


\section{Bibliografia}

GUIMERÀ, J. et altri (1992).- Geologia (II). Història Natural dels Països Catalans. Vol. 2, 547 pag. Enciclopèdia Catalana, S.A. Barcelona.

MAESTRE, A. (1845).- Descripción geognòstica del Distrito Minero de Cataluña y Aragón. Anales de Minas, tomo iil. Madrid.

MATA-PERELLÓ,J.M. (1991).- Els Minerals de Catalunya. Arxius de la Secció de Ciències de I'Institut d'Estudis Catalans, vol.47, 545 pag. Barcelona.

MATA-PERELLÓ, J.M. (1995).- Itinerari geològic i mineralògic per l'Alta Ribagorça: des de Malpàs a Senet. Inèdit. 8 pàgines. Manresa.

MATA-PERELLÓ, J.M. (1996a).- Selecció d’itineraris geològicos i mineralògics per les terres de Lleida. Pub. Museu de Geologia "Valentí Masachs", 72 pàgines. Manresa.

MATA-PERELLÓ, J.M. (1996b).- Itinerari geològico-mineralògic per I’Alta Ribagorça i per la Val d'Aran: des de Malpàs a Vielha, i des del Pont de Suert a Cerler. Inèdit, 14 pàgines. Manresa

MATA-PERELLÓ, J.M. (1998).- Itinerari geològic i mineralògic per I’Alta Ribagorça i per la Vall de Benasc (Ball de Benás): des de Malpas a Senet, i des de Vilaller a Castillo de Sos. Inèdit, 12 pàgines. Manresa.

MATA-PERELLÓ, J. M. (2000).- Recorregut de recerca geològica i mineralògica per les comarques de l'Alta Ribagorça i de la Val d'Aran: des de Malpàs al Túnel de Vielha, per Pont de Suert. Terra Endins, $n^{\circ} 18,10$ pàg. Manresa.

MATA-PERELLÓ, J.M. (2001).- Recorregut de recerca geològica i mineralògica per les comarques de l'Alta Ribagorça i de la Val d'Aran: des de Malpàs al túnel de Vielha per Pont de Suert. Terra Endins, sèrie $B, \mathrm{n}^{\circ} 18,15$ pag. Manresa.

MATA-PERELLÓ, J. M. (2002).- Recorregut de recerca de geològica i mineralògica per les comarques de l'Alta Ribagorça i del Pallars Jussà: des de la Pressa de Colomers a Malpàs i a la Vall de Manyanet. Inèdit. 12 pàgines. Manresa.

MATA-PERELLÓ, J. M. (2013).- Recorregut de recerca geològica i mineralògica per les comarques del Pallars Jussà i de l'Alta Ribagorça: des de la Mola d'Amunt a Sentís, Sas, Erta, Paranyera i a Malpàs. Inèdit. 12 pàgines. Manresa.

MATA-PERELLÓ, J.M. i MATA LLEONART, R. (2000).- Recorregut de recerca geològica i mineralògica per les comarques del Pallars Jussà i de I'Alta Ribagorça: des de Senterada al Pont de Malpàs, Terra Endins, nº 17, 7 pàg. Manresa.

MATA-PERELLÓ, J.M. i SANZ BALAGUÉ, J. (1988).- Guia d’identificació de minerals. Edit Parcir, 205 pàg. Manresa.

MATA-PERELLÓ, J.M. i SANZ BALAGUÉ, J. (1993).- Guia de Identificación de Minerales, adaptada fundamentalmente a la Península Ibérica. Edic. Parcir, 243 pàgines Manresa.

RIBA ARDERIU, O. et altri (1976).- Geografia Física dels Països Catalans, Edit. Ketres. Barcelona. 